\title{
Update of the Texaco mortality study 1947-93: part I. Analysis of overall patterns of mortality among refining, research, and petrochemical workers
}

Barbara J Divine, Christine M Hartman, Judy K Wendt

\begin{abstract}
Objective-To update information on the workers of the Texaco mortality study to determine if the patterns of mortality have changed with 16 additional years of follow up.

Subjects and methods-All workers were employed for $\geqslant 5$ years at company refineries, petrochemical plants, and research laboratories from 1947-93. The cohort now consists of 28480 employees with an average of $\geqslant 20$ years of follow up.

Results-The overall mortality, and most cause specific mortalities were lower than or similar to those for the general population of the United States. For white men $(86 \%$ of the cohort), there were 8873 observed deaths and 11181 expected resulting in a significantly lower standardised mortality ratio (SMR) of 79. There were significant deficits for all the leading causes of death in the United States including all cancers, cancer of the lung, stroke, heart disease, respiratory disease, and accidents. Slightly increased mortality was found for cancer of the pancreas, cancer of the brain and central nervous system, leukaemia, and cancer of other lymphatic tissue. For cancer of the bone, the SMR was $162(95 \%$ confidence interval (95\% CI) 86 to 278), and for benign and unspecified neoplasms, it was 152 (95\% CI 109 to 206). Overall mortality patterns for non-white men and women were similar to those for white men. Mortality patterns for white men were also examined by duration of employment, time first employed, location, and by job and process unit. There were significantly increased SMRs for brain cancer for those people employed as laboratory workers and on units with motor oil and for cancer of other lymphatic tissue for people employed on the fluid catalytic cracking unit. Conclusions-The results of the updated study showed a favourable mortality experience for employees in the Texaco mortality study compared with the United States population. There were a few increases found consistently including, but not limited to, brain cancer and cancer of other lymphatic tissue. These increases led to additional analyses that will be discussed in the accompanying paper.

(Occup Environ Med 1999;56:167-173)
\end{abstract}

Keywords: petroleum; chemical industry; occupational cancer; mortality

Texaco published two epidemiological reports in 1985 and 1986 on the patterns of mortality at company refineries, petrochemical plants, and research laboratories. ${ }^{12}$ The Texaco mortality study cohort consisted of over 21000 workers whose mortality experience was followed up from 1947 to 1977. Results from these earlier analyses were generally favourable in that the overall mortality and most cause specific mortalities were lower than or similar to those for the general United States population.

White men experienced significant deficits for all causes of death combined, all malignant neoplasms, cancer of the lung, stroke, arteriosclerotic heart disease, respiratory disease, and accidents. Increased standardised mortality ratios (SMRs) were found for cancer of the pancreas, cancer of the brain, Hodgkin's disease, leukaemia, cancer of other lymphatic tissue, and benign and unspecified neoplasms, but none was significant. About half of the deaths in the benign and unspecified neoplasm category were from benign and unspecified neoplasms of the brain, and increased SMRs were found for brain tumours in people ever employed in the quality control and research laboratories.

This study expands and updates the earlier cohort by adding people who had met the cohort eligibility requirements since the earlier study end date of 31 December 1977, adding current and former employees of three former Getty Oil Company refineries acquired by Texaco as part of its purchase of Getty Oil, and extending vital status follow up to 31 December 1993. The large size of the cohort and the additional 16 years of follow up add substantial power to the original cohort to determine if the earlier observed patterns of mortality have continued. Information on complete work histories for all cohort members made it possible to examine mortality patterns in detail and to compare the results to other studies of refinery workers which have reported increased mortality from leukaemia, malignant melanoma, benign and unspecified neoplasms, kidney cancer, and mesothelioma. ${ }^{3-8}$

The cohort includes employees from 15 refineries (all but seven of which have now been sold or closed), two former packaging facilities, five chemical plants (all of which have been 
sold or closed), and three research laboratories. The factories are in 11 states, began operations from 1903 to 1967 , and range in size from 140 to 10060 former and current employees.

\section{Materials and methods}

The original study cohort included all employees of Texaco who worked at selected refinery, petrochemical, and research establishments at least one day between 1 January 1947 and 31 December 1977; were employed at these for a cumulative total of $\geqslant 5$ years; and were employed there on either their last day of employment or the original study end date. ${ }^{1}$ Employees of other departments at these factories, employees who transferred to nonparticipating locations before the study end date, and employees at the former Jefferson Chemical Company who ended employment before 1955 were excluded. Because the duration of employment requirement was longer than usual for a cohort mortality study, information on people employed for $\geqslant 1$ year was collected for the largest refinery in the study and for the three former Getty refineries. Comparisons of the patterns of mortality for the 1 year versus the 5 year cohorts showed no major differences.

Original study participants were identified from personnel separation rosters listing all employees who left the company between 1947 and 1978 and from computerised personnel files of workers employed in 1978. One hundred and seventeen men and eight women listed on the separation rosters for whom no work history could be found were included in the overall analyses, but not in the job specific analyses.

The current cohort consists of members of the original cohort as well as additional people employed at the Texaco mortality study factories who met the eligibility criteria by 31 December 1993. New cohort members were identified with computerised personnel information as well as by reviewing records of employees at the three Getty refineries that Texaco acquired in 1985. Data collected on each employee included name, social security number, race, sex, date of birth, and a complete history (if available) of all jobs held at any of the participating factories. Updated work history and employment status information on people employed in 1978 was obtained from the computerised personnel system as was information on new cohort members. Original records were requested if parts of the work history had not been computerised. People (1\%) whose records lacked information about sex or race were assumed to be white men for the analysis.

Vital status information to 31 December 1993 for former employees was obtained from Texaco files where available, the National Death Index, the Social Security Administration master beneficiary record file, and the Health Care Financing Administration. People identified as alive by the Social Security Administration in 1985 were assumed to be alive if no matching death record was found by the National Death Index. Copies of death certificates were obtained from company files or from the health departments in the states where the deaths occurred. The deaths were coded by a trained nosologist to the eighth revision of the international classification of diseases (ICD-8) as the eighth revision is the one used by the analysis program.

Analyses of patterns of mortality were performed with the program developed by Monson. ${ }^{9}$ The program uses the observed and expected numbers of deaths for specific causes to calculate SMRs, with the United States population as the comparison group. Ninety five per cent confidence intervals (95\% CIs) were calculated assuming a Poisson distribution for the observed frequency in the numerator of the SMR. Person-years of observation were counted from the date the person attained 5 years of employment or the date the study began, whichever came last, until the study end date, the date of death, or the date lost to follow up, whichever came first. For subcohort analyses, person-years of observation were counted from the date the person attained the required duration of employment in that group or the date the study began, whichever came last.

Total mortality was examined by race and sex. Because of the few non-white women $(0.8 \%)$, patterns of mortality for all women were examined with the mortalities for United States white women as the comparison. For white men, patterns of mortality were examined by duration of employment, by time first employed, by plant, by job and unit, and by grouped jobs and units (based on the potential for similar tasks and exposures) by duration of employment in the job or unit. For the analysis of mortality by date first employed, the year 1950 was chosen as a dividing date between the early years of the petroleum industry and the later years that tended to have more complex process units and increasing production. Also, about half of the cohort was first employed before 1950, and half after 1950. People who had numerous jobs could be counted in more than one job and unit analysis. See table 1 for a brief description of the potential exposures associated with some of the jobs and units examined.

\section{Results}

The study cohort included 28480 people (table 2) with 738454 total person-years of observation. Over $92 \%$ of the cohort members were men, and of these, over $93 \%$ were white. Over $85 \%$ of the women were white. Because the cohort overwhelmingly consisted of white men $(86.4 \%)$, the following descriptive statistics refer only to that group. Thirty six per cent of the cohort was dead, only $2.5 \%$ were lost to follow up, and death certificates were obtained for all but $1.9 \%$ of the deaths.

As of 31 December 1993, only 19\% of the cohort was still employed, $44.6 \%$ had retired, and $2.5 \%$ had left because of a permanent disability. Thirty eight per cent were employed by the company at study locations for $\geqslant 30$ years. Forty per cent of the cohort were born before 1920, and a quarter were first employed before 1940. Sixty seven per cent of the dead employ- 
Table 1 Texaco mortality study: potential exposures by job and process unit group

\begin{tabular}{ll}
\hline fob or process unit & Description (potential for exposure) \\
\hline $\begin{array}{l}\text { Office, professional, and supervisor } \\
\text { Operators }\end{array}$ & $\begin{array}{l}\text { Facility background exposure } \\
\text { Operate all process units in facility (potentially exposed to all chemicals present at facility) } \\
\text { Craft, maintenance } \\
\text { exposure to asbestos) }\end{array}$ \\
Laboratory staff & $\begin{array}{l}\text { Provide quality assurance checks, pilot plant operations, research activities; potentially exposed to all chemicals present at } \\
\text { facility (no asbestos) }\end{array}$ \\
Fluid catalytic cracking unit (FCCU) & $\begin{array}{l}\text { Uses mid-distillates as input, main product is gasoline; residual heavy ends give potential for exposure to polynuclear } \\
\text { aromatics (PNAs) (no benzene) }\end{array}$ \\
Pipefitters and boilermakers & $\begin{array}{l}\text { Could work in shop or any unit in factory; potentially exposed to all chemicals present at factory, including asbestos (under } \\
\text { certain circumstances, potential for exposure is high) } \\
\text { Uses crude oil as input; produces gasoline, middle distillates, and heavy bottoms such as asphalt (potential for exposure to } \\
\text { PNAs) }\end{array}$ \\
Crude stills & $\begin{array}{l}\text { Used to remove wax, solids, and PNAs from motor oils; potential exposure to removed materials, motor oils, and methyl } \\
\text { ethyl ketone-toluene (no benzene exposure) } \\
\text { Potential for exposure to coke dust, PNAs, and heavy ends (no benzene or asbestos) }\end{array}$ \\
Motor oil units & $\begin{array}{l}\text { Potential for high exposure to all factory streams and products (no asbestos) } \\
\text { Delayed coking unit (DCU) }\end{array}$ \\
Receipt, pumping and storage (RPS)
\end{tabular}

ees were $\geqslant 65$ years at the time of death with half of the deaths occurring since the end date of the previous study, 31 December 1977.

Table 3 shows the patterns of mortality for white and non-white men and for women. For white men, there were 8873 observed deaths and 11181 expected giving a significantly lower all causes SMR of 79. Significant deficits were also found for the leading causes of death in the United States population: all cancers $(\mathrm{SMR}=81)$, digestive system cancers (SMR $=77)$, lung cancer $(\mathrm{SMR}=67)$, arteriosclerotic heart disease (ASHD, SMR=82), stroke $(\mathrm{SMR}=86)$, non-malignant respiratory disease $(S M R=65)$, and all external causes $(\mathrm{SMR}=62)$. The observed and expected numbers of deaths were similar for leukaemia, cancer of the pancreas, cancer of the brain and central nervous system, and cancer of other lymphatic tissue. Standardised mortality ratios $>100$ were found for benign and unspecified neoplasms $(S M R=152)$, and bone cancer $(S M R=162)$. Only the SMR for benign and unspecified neoplasms was significantly increased.

The increases for the causes of death from benign and unspecified neoplasms were examined further. Twenty one $(51 \%)$ of the benign and unspecified neoplasms were benign $(n=3)$ and unspecified brain tumours $(n=18)$. Because many of the unspecified brain tumours could be malignant, it was decided to combine all the brain tumours together. If the deaths from benign and unspecified brain tumours were combined with the malignancies of the brain and central nervous system, there were 85 observed deaths and 75 expected, giving an SMR for brain tumours of 113 , which is not significant.

An examination of the deaths from bone cancer showed that 10 of the 13 decedents died after 1978 when the ninth revision of the ICD codes (ICD-9) came into effect. In ICD-9, the coding rules were changed so that metastatic bone tumours were no longer classified with

Table 2 Texaco mortality study: total cohort by vital status ( $(\%)$ )

\begin{tabular}{lcccr}
\hline $\begin{array}{l}\text { Vital status on } 31 \\
\text { December 1993 }\end{array}$ & White men & Non-white men & Women & Total \\
\hline Alive & $15115(61.4)$ & $1303(73.1)$ & $1691(80.8)$ & $18109(63.6)$ \\
Dead & $8873(36.1)$ & $437(24.5)$ & $265(12.7)$ & $9575(33.6)$ \\
Unknown & $616(2.5)$ & $43(2.4)$ & $137(6.5)$ & $796(2.8)$ \\
Total & $24604(86.4)$ & $1783(6.3)$ & $2093(7.3)$ & 28480 \\
\hline
\end{tabular}

primary bone tumours. If the ICD-9 had been used to classify the underlying causes of death for the bone cancer death certificates instead of ICD-8, seven of the deaths would not have been coded to cancer of the bone. The SMR for bone cancer would then have been 75 .

For non-white men, there were 437 observed deaths and 563 expected giving a significant all causes SMR of 78 . Deficits were also found for many of the major causes of death-such as all cancers $(\mathrm{SMR}=81)$, cancer of the digestive system $(S M R=90)$, lung cancer $(S M R=82)$, prostate cancer $(\mathrm{SMR}=52)$, lymphohaematopoietic cancer $(\mathrm{SMR}=36)$, stroke $(\mathrm{SMR}=77)$, and non-malignant respiratory disease $(\mathrm{SMR}=55)$. The SMRs $>100$ were for cancer of the stomach $(S M R=119)$, cancer of the pancreas $(\mathrm{SMR}=119)$, diabetes $(\mathrm{SMR}=137)$, and cancer of the brain and central nervous system $(\mathrm{SMR}=287)$. None of these were significant.

For women, there were 265 observed deaths and 325 expected giving a significant deficit for the all causes $\mathrm{SMR}=82$. Deficits were also found for all the leading causes of death including all cancers (SMR $=76)$, digestive system cancers $(\mathrm{SMR}=50)$, colon cancer $(\mathrm{SMR}=20)$, lung cancer $(\mathrm{SMR}=79)$, breast cancer $\quad(\mathrm{SMR}=71), \quad$ diabetes $\quad(\mathrm{SMR}=38)$, ASHD (SMR=75), stroke (SMR=83), nonmalignant respiratory disease $(\mathrm{SMR}=69)$, pneumonia $(\mathrm{SMR}=25)$, and all external causes $(\mathrm{SMR}=83)$. Standardised mortality ratios $>100$ were found for several cancer sites including cancer of the stomach $(\mathrm{SMR}=126)$, leukaemia $(S M R=129)$, uterine cancer $(\mathrm{SMR}=143)$, and cancer of other lymphatic tissue $(\mathrm{SMR}=209)$. None of these was significant.

All further results apply only to the subcohort of white men and represent only a small subset of the total analyses. In general, the reported results are for the largest job unit groups studied or are for subgroups with results that differed from those expected and led to further cause specific analyses.

Table 4 shows the patterns of mortality by duration of employment. The patterns were similar for all of the groups, and all had significant deficits for all causes of death, all cancers, lung cancer, ASHD, respiratory disease, and all external causes of death. There were significantly increased SMRs for benign and unspecified neoplasms for those employed $\geqslant 30$ years 
Table 3 Texaco mortality study: SMRs for selected causes of death, 1947-93

\begin{tabular}{|c|c|c|c|c|c|c|c|c|c|c|}
\hline \multirow{3}{*}{$\begin{array}{l}\text { Cause of death }(I C D A-8) \\
\text { All causes }\end{array}$} & \multicolumn{3}{|c|}{ White men $n=24604, p-y=653857$} & \multicolumn{4}{|c|}{$\begin{array}{l}\text { Non-white men } n=1783 \text {, } \\
p-y=36552\end{array}$} & \multicolumn{3}{|c|}{ All Women $n=2093, p-y=48045$} \\
\hline & \multirow{2}{*}{$\begin{array}{l}\begin{array}{l}\text { Observed } \\
\text { deaths }\end{array} \\
8873\end{array}$} & \multirow{2}{*}{$\begin{array}{c}S M R^{a} \\
79\end{array}$} & $95 \% C I$ & \multirow{2}{*}{$\begin{array}{l}\begin{array}{l}\text { Observed } \\
\text { deaths }\end{array} \\
437\end{array}$} & \multirow{2}{*}{$\begin{array}{c}S M R \\
78\end{array}$} & \multicolumn{2}{|c|}{$95 \% C I$} & \multirow{2}{*}{$\begin{array}{l}\begin{array}{l}\text { Observed } \\
\text { deaths }\end{array} \\
265\end{array}$} & \multirow{2}{*}{$\begin{array}{c}S M R \\
82\end{array}$} & $95 \% C I$ \\
\hline & & & 78 to 81 & & & 71 to & 85 & & & 72 to 92 \\
\hline All cancers (140-209) & 1975 & 81 & 77 to 84 & 95 & 81 & 65 to & 98 & 74 & 76 & 60 to 96 \\
\hline Cancer of digestive system (150-159) & 505 & 77 & 70 to 84 & 31 & 90 & 61 to & 128 & 11 & 50 & 25 to 90 \\
\hline Cancer of stomach (151) & 88 & 80 & 64 to 98 & 9 & 119 & 54 to & 226 & 3 & 126 & 25 to 367 \\
\hline Cancer of large intestine (153) & 184 & 78 & 68 to 91 & 8 & 98 & 42 to & 193 & 2 & 20 & 2 to 74 \\
\hline Cancer of pancreas (157) & 132 & 105 & 88 to 125 & 7 & 119 & 48 to & 244 & 4 & 91 & 24 to 232 \\
\hline Cancer of lung (162) & 537 & 67 & 61 to 73 & 31 & 82 & 56 to & 116 & 13 & 79 & 42 to 135 \\
\hline Cancer of bone (170) & 13 & 162 & 86 to 278 & 1 & 296 & 4 to 1 & 1650 & 0 & 0 & 0 to 1503 \\
\hline Cancer of skin (172-173) & 43 & 98 & 71 to 132 & 1 & 133 & 2 to & 742 & 1 & 69 & 1 to 383 \\
\hline Cancer of breast (174) & & & & & & & & 15 & 71 & 40 to 118 \\
\hline Cancer of cervix (180) & & & & & & & & 1 & 30 & 0 to 167 \\
\hline Cancer of uterus (181) & & & & & & & & 4 & 143 & 39 to 367 \\
\hline Cancer of prostate (185) & 218 & 99 & 87 to 114 & 7 & 52 & 21 to & 107 & & & \\
\hline Cancer of bladder (188) & 63 & 83 & 64 to 107 & 2 & 100 & 11 to & 360 & 2 & 195 & 22 to 706 \\
\hline Cancer of kidney (189) & 55 & 94 & 71 to 122 & 1 & 53 & 1 to & 293 & 1 & 65 & 1 to 360 \\
\hline Cancer of brain and CNS (191-192) & 64 & 108 & 83 to 137 & 4 & 287 & 77 to & 735 & 1 & 40 & 1 to 221 \\
\hline Lymphatic and haematopoietic cancer (200-209) & 226 & 99 & 87 to 113 & 3 & 36 & 7 to & 106 & 11 & 131 & 65 to 234 \\
\hline Lymphosarcoma and reticulosarcoma (200) & 26 & 75 & 49 to 110 & 0 & 0 & 0 to & 417 & 0 & 0 & 0 to 309 \\
\hline Hodgkin's disease (201) & 17 & 98 & 57 to 156 & 0 & 0 & 0 to & 615 & 0 & 0 & 0 to 618 \\
\hline Leukaemia (204-207) & 93 & 101 & 81 to 123 & 0 & 0 & 0 to & 122 & 4 & 129 & 35 to 331 \\
\hline Other lymphatic tissue $(202,203,208)$ & 85 & 109 & 87 to 135 & 3 & 81 & 16 to & 237 & 7 & 209 & 84 to 431 \\
\hline Benign and unspecified neoplasms (210-239) & 41 & 152 & 109 to 206 & 2 & 150 & 17 to & 543 & 0 & 0 & 0 to 267 \\
\hline Diabetes mellitus (250) & 128 & 77 & 65 to 90 & 14 & 137 & 74 to & 230 & 3 & 38 & 8 to 112 \\
\hline Arteriosclerotic heart disease $(410-413)$ & 3209 & 82 & 79 to 84 & 113 & 93 & 76 to & 111 & 61 & 75 & 57 to 96 \\
\hline Vascular lesions of CNS (430-438) & 645 & 86 & 79 to 92 & 35 & 77 & 54 to & 107 & 22 & 83 & 52 to 125 \\
\hline Non-malignant respiratory disease (460-519) & 549 & 65 & 60 to 71 & 19 & 55 & 33 to & 87 & 14 & 69 & 38 to 116 \\
\hline Pneumonia $(480-486)$ & 226 & 74 & 65 to 85 & 9 & 52 & 24 to & 98 & 2 & 25 & 3 to 89 \\
\hline Cirrhosis of liver (571) & 101 & 47 & 38 to 57 & 2 & 14 & 2 to & 50 & 5 & 81 & 26 to 188 \\
\hline All external causes (800-998) & 457 & 62 & 56 to 68 & 61 & 91 & 70 to & 117 & 14 & 83 & 45 to 139 \\
\hline
\end{tabular}

$\mathrm{p}-\mathrm{y}=$ Person-years.

$(\mathrm{SMR}=184)$ and for cancer of other lymphatic tissue for those employed 20-30 years $(\mathrm{SMR}=165)$. The SMR for cancer of other lymphatic tissue for those employed $\geqslant 30$ years was not increased.

Table 5 shows the patterns of mortality by time first employed, either before or after 1950 . The all causes SMR was 82 for the group first employed before 1950 and 64 for the group first employed after 1950. The observed and expected numbers of deaths were similar for cancer of the pancreas, cancer of the skin, can- cer of the brain and central nervous system, leukaemia, and cancer of other lymphatic tissue for the group first employed before 1950. The SMR for benign and unspecified neoplasms was 146 and is of borderline significance. For the group first employed in 1950 and later, there were slightly increased SMRs for cancer of the pancreas and Hodgkin's disease, and the SMR for benign and unspecified neoplasms was 176 .

Almost all of the analyses by job and process unit showed deficits for all causes of death, all

Table 4 Texaco mortality study: SMRs for selected causes of death, 1947-93, by duration of employment

\begin{tabular}{|c|c|c|c|c|c|c|c|c|c|c|c|c|}
\hline \multirow[b]{2}{*}{ Cause of death (ICDA-8) } & \multicolumn{3}{|c|}{$\begin{array}{l}\text { White men employed }<10 \\
y n=4017, p-y=138057\end{array}$} & \multicolumn{3}{|c|}{$\begin{array}{l}\text { White men employed 10-19 } \\
y n=5372, p-y=187250\end{array}$} & \multicolumn{3}{|c|}{$\begin{array}{l}\text { White men employed 20-29y } \\
n=5759, p-y=157474\end{array}$} & \multicolumn{3}{|c|}{$\begin{array}{l}\text { White men employed }>30 y \\
n=9456, p-y=171076\end{array}$} \\
\hline & $\begin{array}{l}\text { Observed } \\
\text { deaths }\end{array}$ & $S M R$ & $95 \% C I$ & $\begin{array}{l}\text { Observed } \\
\text { deaths }\end{array}$ & $S M R$ & $95 \% C I$ & $\begin{array}{l}\text { Observed } \\
\text { deaths }\end{array}$ & $S M R$ & $95 \% C I$ & $\begin{array}{l}\text { Observed } \\
\text { deaths }\end{array}$ & $S M R$ & $95 \% C I$ \\
\hline All causes & 567 & 71 & 65 to 77 & 1263 & 80 & 76 to 85 & 2324 & 83 & 79 to 86 & 4719 & 79 & 76 to 81 \\
\hline All cancers (140-209) & 119 & 73 & 60 to 87 & 267 & 84 & 74 to 95 & 514 & 84 & 76 to 91 & 1075 & 80 & 75 to 85 \\
\hline Cancer of digestive system $(150-159)$ & 29 & 71 & 48 to 102 & 68 & 80 & 62 to 102 & 132 & 79 & 66 to 94 & 276 & 76 & 67 to 85 \\
\hline Cancer of stomach (151) & 6 & 88 & 32 to 192 & 10 & 66 & 32 to 122 & 28 & 96 & 64 to 139 & 44 & 74 & 54 to 100 \\
\hline Cancer of large intestine (153) & 11 & 77 & 39 to 139 & 24 & 83 & 53 to 124 & 40 & 69 & 50 to 94 & 109 & 81 & 67 to 98 \\
\hline Cancer of pancreas (157) & 5 & 64 & 21 to 150 & 19 & 117 & 71 to 183 & 40 & 125 & 89 to 170 & 68 & 98 & 76 to 124 \\
\hline Cancer of lung (162) & 30 & 57 & 38 to 81 & 63 & 63 & 48 to 80 & 142 & 69 & 59 to 82 & 302 & 68 & 61 to 76 \\
\hline Cancer of bone $(170)$ & 0 & 0 & 0 to 524 & 1 & 71 & 1 to 397 & 4 & 182 & 49 to 465 & 8 & 215 & 93 to 425 \\
\hline Cancer of skin (172-173) & 4 & 87 & 23 to 223 & 5 & 63 & 20 to 148 & 12 & 108 & 56 to 189 & 22 & 109 & 68 to 165 \\
\hline Cancer of prostate (185) & 8 & 83 & 36 to 164 & 23 & 108 & 68 to 162 & 52 & 105 & 78 to 138 & 135 & 97 & 82 to 115 \\
\hline Cancer of bladder (188) & 4 & 108 & 29 to 277 & 6 & 71 & 26 to 155 & 13 & 71 & 38 to 122 & 40 & 88 & 63 to 120 \\
\hline Cancer of kidney (189) & 3 & 73 & 15 to 214 & 8 & 98 & 42 to 192 & 18 & 117 & 69 to 185 & 26 & 84 & 55 to 123 \\
\hline Cancer of brain and CNS (191-192) & 8 & 125 & 54 to 246 & 14 & 125 & 68 to 210 & 16 & 100 & 57 to 162 & 26 & 100 & 66 to 147 \\
\hline Lymphatic and haematopoietic cancer & & & & & & & & & & & & \\
\hline$(200-209)$ & 18 & 95 & 56 to 150 & 39 & 114 & 81 to 156 & 70 & 124 & 97 to 157 & 99 & 84 & 68 to 102 \\
\hline Lymphosarcoma and reticulosarcoma (200) & 3 & 107 & 22 to 313 & 8 & 136 & 58 to 267 & 10 & 109 & 52 to 200 & 5 & 30 & 10 to 70 \\
\hline Hodgkin's disease (201) & 3 & 111 & 22 to 325 & 5 & 116 & 37 to 271 & 4 & 89 & 24 to 228 & 5 & 85 & 27 to 197 \\
\hline Leukaemia (204-207) & 7 & 93 & 37 to 192 & 17 & 125 & 73 to 200 & 23 & 101 & 64 to 152 & 46 & 94 & 69 to 126 \\
\hline Other lymphatic tissue $(202,203,208)$ & 5 & 91 & 29 to 212 & 8 & 80 & 34 to 158 & 31 & 165 & 112 to 234 & 41 & 94 & 68 to 128 \\
\hline Benign and unspecified neoplasms (210-239) & 2 & 83 & 9 to 301 & 9 & 196 & 89 to 371 & 6 & 86 & 31 to 187 & 24 & 184 & 118 to 274 \\
\hline Diabetes mellitus (250) & 2 & 18 & 2 to 64 & 13 & 58 & 31 to 98 & 32 & 79 & 54 to 112 & 81 & 91 & 72 to 113 \\
\hline Arteriosclerotic heart disease $\quad(410-413)$ & 149 & 66 & 56 to 77 & 439 & 86 & 78 to 94 & 930 & 93 & 87 to 99 & 1691 & 77 & 73 to 81 \\
\hline Vascular lesions of CNS (430-438) & 39 & 103 & 73 to 141 & 74 & 82 & 64 to 102 & 133 & 73 & 61 to 86 & 399 & 90 & 82 to 100 \\
\hline Non-malignant respiratory disease $(460-519)$ & 31 & 69 & 47 to 89 & 74 & 77 & 60 to 96 & 149 & 75 & 63 to 88 & 295 & 59 & 52 to 66 \\
\hline Pneumonia $(480-486)$ & 12 & 73 & 38 to 128 & 34 & 92 & 64 to 128 & 59 & 83 & 63 to 107 & 121 & 68 & 56 to 81 \\
\hline Cirrhosis of liver (571) & 5 & 23 & 8 to 55 & 20 & 47 & 29 to 73 & 25 & 39 & 25 to 58 & 51 & 57 & 42 to 75 \\
\hline All external causes (800-998) & 84 & 60 & 48 to 74 & 110 & 58 & 48 to 70 & 104 & 57 & 47 to 70 & 159 & 69 & 59 to 81 \\
\hline
\end{tabular}

$\mathrm{p}-\mathrm{y}=$ Person-years. 
Table 5 Texaco mortality study: SMRs for selected causes of deathby time first employed, 1947-93

\begin{tabular}{|c|c|c|c|c|c|c|}
\hline \multirow[b]{2}{*}{ Cause of death (ICDA) } & \multicolumn{3}{|c|}{$\begin{array}{l}\text { White men employed before } 1950 \\
n=11649, p-y=383640\end{array}$} & \multicolumn{3}{|c|}{$\begin{array}{l}\text { White men employed } 1950 \text { and after } \\
n=12955, p-y=270302\end{array}$} \\
\hline & $\begin{array}{l}\text { Observed } \\
\text { deaths }\end{array}$ & $S M R$ & $95 \% C I$ & $\begin{array}{l}\text { Observed } \\
\text { deaths }\end{array}$ & $S M R$ & $95 \% C I$ \\
\hline All causes & 7644 & 82 & 81 to 84 & 1229 & 64 & 61 to 68 \\
\hline All cancers (140-209) & 1655 & 84 & 80 to 88 & 320 & 68 & 61 to 76 \\
\hline Cancer of digestive system $(150-159)$ & 412 & 75 & 68 to 83 & 93 & 84 & 68 to 103 \\
\hline Cancer of stomach (151) & 75 & 79 & 62 to 99 & 13 & 84 & 44 to 143 \\
\hline Cancer of large intestine (153) & 152 & 78 & 66 to 92 & 32 & 80 & 54 to 112 \\
\hline Cancer of pancreas (157) & 105 & 102 & 83 to 124 & 27 & 119 & 78 to 173 \\
\hline Cancer of lung (162) & 449 & 72 & 65 to 78 & 88 & 50 & 40 to 62 \\
\hline Cancer of bone (170) & 13 & 196 & 104 to 335 & 0 & 0 & 0 to 267 \\
\hline Cancer of skin (172-173) & 32 & 105 & 72 to 148 & 11 & 82 & 41 to 147 \\
\hline Cancer of prostate (185) & 195 & 100 & 86 to 115 & 23 & 98 & 62 to 147 \\
\hline Cancer of bladder (188) & 55 & 83 & 62 to 108 & 8 & 88 & 38 to 173 \\
\hline Cancer of kidney (189) & 43 & 94 & 68 to 126 & 12 & 94 & 49 to 164 \\
\hline Cancer of brain and CNS (191-192) & 48 & 113 & 83 to 150 & 16 & 95 & 54 to 154 \\
\hline Lymphatic and haematopoietic cancer (200-209) & 187 & 104 & 90 to 120 & 39 & 81 & 58 to 111 \\
\hline Lymphosarcoma and reticulosarcoma (200) & 20 & 70 & 43 to 109 & 6 & 99 & 36 to 215 \\
\hline Hodgkin's disease (201) & 12 & 93 & 48 to 163 & 5 & 111 & 36 to 258 \\
\hline Leukaemia (204-207) & 84 & 113 & 90 to 140 & 9 & 50 & 23 to 94 \\
\hline Other lymphatic tissue $(202,203,208)$ & 67 & 113 & 87 to 143 & 18 & 98 & 58 to 155 \\
\hline Benign and unspecified neoplasms (210-239) & 32 & 146 & 100 to 207 & 9 & 176 & 80 to 335 \\
\hline Diabetes mellitus (250) & 116 & 86 & 71 to 103 & 12 & 42 & 22 to 73 \\
\hline Arteriosclerotic heart disease $\quad(410-413)$ & 2833 & 84 & 81 to 87 & 376 & 66 & 60 to 73 \\
\hline Vascular lesions of CNS (430-438) & 596 & 88 & 81 to 95 & 49 & 65 & 48 to 86 \\
\hline Non-malignant respiratory disease $(460-519)$ & 495 & 68 & 62 to 74 & 54 & 49 & 37 to 64 \\
\hline Pneumonia (480-486) & 206 & 76 & 66 to 88 & 20 & 58 & 35 to 89 \\
\hline Cirrhosis of liver (571) & 79 & 51 & 40 to 63 & 22 & 36 & 22 to 54 \\
\hline All external causes (800-998) & 318 & 66 & 59 to 74 & 139 & 54 & 45 to 63 \\
\hline
\end{tabular}

p-y=Person-years.

cancer, digestive system cancer, lung cancer, ASHD, stroke, and all external causes of death similar to those found for all white men. Therefore, the following table shows only the results for selected neoplasms for these job subgroups.

Table 6 shows the patterns of mortality for those employed in selected job and process groups mentioned below for at least 5 years. For those who were employed in office jobs, as managers and supervisors, or in professional jobs, there were non-significantly increased SMRs for cancer of the pancreas, bone cancer, skin cancer, prostate cancer, bladder cancer, and benign and unspecified neoplasms.

For those employed as operators and controlmen, the SMR for cancer of other lymphatic tissue were increased as was the SMR for benign and unspecified neoplasms for those ever employed in maintenance.
For those ever employed as laboratory staff, there were increased SMRs for skin cancer, cancer of the brain and central nervous system, and benign and unspecified neoplasms. For people employed on a fluid catalytic cracking unit, there was a significantly increased SMR for all lymphohaematopoietic cancer that partly resulted from a significantly increased SMR for cancer of other lymphatic tissue. Although the SMRs for the other lymphohaematopoietic cancers were also increased, they were not significant. The higher SMRs noted for skin cancer, kidney cancer, cancer of the brain and central nervous system, and benign and unspecified neoplasms were not significant.

For people employed as pipefitters or boilermakers, there were increased SMRs for bone cancer, kidney cancer, leukaemia, cancer of other lymphatic tissue, and benign and un-

Table 6 Texaco mortality study: SMRs for selected neoplasms, for selected jobs and process units, 1947-93

\begin{tabular}{|c|c|c|c|c|c|c|c|c|c|}
\hline \multirow[b]{2}{*}{ Cause of death (ICDA-8) } & \multicolumn{3}{|c|}{$\begin{array}{l}\text { Office, professional, supervisor } \\
\text { employed }>5 \text { years white males } \\
n=7586, p-y=168489\end{array}$} & \multicolumn{3}{|c|}{$\begin{array}{l}\text { Controlmen, operators employed } \\
>5 \text { y wgite men } n=9542, \\
p-y=247983\end{array}$} & \multicolumn{3}{|c|}{$\begin{array}{l}\text { Craft, maintenance employed } \\
>5 \text { y white men } n=7910 \text {, } \\
p-y=220713\end{array}$} \\
\hline & $\begin{array}{l}\text { Observed } \\
\text { deaths }\end{array}$ & $S M R$ & $95 \% C I$ & $\begin{array}{l}\text { Observed } \\
\text { deaths }\end{array}$ & $S M R$ & $95 \% C I$ & $\begin{array}{l}\text { Observed } \\
\text { deaths }\end{array}$ & $S M R$ & $95 \% C I$ \\
\hline All cancers $(140-209)$ & 590 & 75 & 69 to 81 & 801 & 81 & 75 to 86 & 738 & 84 & 78 to 91 \\
\hline Cancer of digestive system (150-159) & 166 & 78 & 67 to 91 & 203 & 75 & 65 to 86 & 193 & 82 & 70 to 94 \\
\hline Cancer of stomach (151) & 19 & 54 & 32 to 84 & 41 & 89 & 64 to 120 & 36 & 90 & 63 to 125 \\
\hline Cancer of large intestine (153) & 65 & 85 & 66 to 108 & 63 & 66 & 50 to 84 & 62 & 74 & 57 to 95 \\
\hline Cancer of pancreas (157) & 53 & 131 & 98 to 171 & 52 & 101 & 75 to 133 & 56 & 124 & 94 to 161 \\
\hline Cancer of lung (162) & 140 & 54 & 45 to 63 & 223 & 69 & 60 to 79 & 206 & 72 & 63 to 83 \\
\hline Cancer of bone (170) & 5 & 208 & 67 to 486 & 3 & 91 & 18 to 264 & 4 & 139 & 37 to 357 \\
\hline Cancer of skin (172-173) & 18 & 133 & 79 to 210 & 11 & 63 & 32 to 114 & 17 & 111 & 65 to 177 \\
\hline Cancer of prostate (185) & 82 & 111 & 89 to 138 & 98 & 107 & 87 to 130 & 69 & 87 & 68 to 111 \\
\hline Cancer of bladder (188) & 24 & 97 & 62 to 144 & 30 & 95 & 64 to 135 & 21 & 77 & 48 to 118 \\
\hline Cancer of kidney (189) & 15 & 80 & 45 to 131 & 26 & 110 & 72 to 161 & 22 & 105 & 66 to 159 \\
\hline Cancer of brain and CNS (191-192) & 15 & 84 & 47 to 138 & 20 & 85 & 52 to 132 & 22 & 105 & 66 to 160 \\
\hline Lymphatic and hematopoietic cancer (200-209) & 54 & 75 & 57 to 98 & 93 & 101 & 82 to 124 & 71 & 88 & 69 to 111 \\
\hline Lymphosarcoma and reticulosarcoma (200) & 8 & 77 & 33 to 152 & 10 & 70 & 34 to 129 & 5 & 40 & 13 to 94 \\
\hline Leukaemia (204-207) & 23 & 79 & 50 to 118 & 37 & 98 & 69 to 135 & 25 & 76 & 49 to 112 \\
\hline Other lymphatic tissue $(202,203,208)$ & 21 & 82 & 51 to 126 & 40 & 129 & 92 to 175 & 30 & 109 & 74 to 156 \\
\hline Benign and unspecified neoplasms (210-239) & 12 & 146 & 75 to 255 & 10 & 91 & 44 to 168 & 16 & 167 & 95 to 271 \\
\hline
\end{tabular}

$\mathrm{p}-\mathrm{y}=$ Person-years. 
specified neoplasms. Because of increases related to asbestos found in pipefitters in other similar studies, deaths from mesothelioma were reviewed in detail in a further paper. For people employed on the crude stills, the SMR for cancer of other lymphatic tissue is 172 . There were also non-significant increases for pancreas cancer and kidney cancer.

For people who were employed on the motor oil unit, one of the lube oil extraction units, the clay filter plant, or the paraffin plant, there were non-significantly increased SMRs for stomach cancer, pancreatic cancer, bladder cancer, lymphosarcoma, leukaemia, and benign and unspecified neoplasms. The SMR for cancer of the brain and central nervous system was 314 (95\% CI 115 to 684 ).

\section{Discussion}

The patterns of mortality found in this 1993 update of the Texaco mortality study cohort are generally similar to earlier findings on this cohort. ${ }^{12}$ As found in the 1977 study, mortality experience is more favourable for the cohort than the United States population. The cohort again experienced significantly fewer deaths from the leading causes of death in the United States, all causes combined, all cancers, heart disease, non-malignant respiratory disease, and all external causes. As in the earlier study, increased mortality was found for benign and unspecified neoplasms, and this result is now significant. The increased mortality from cancer of the bone, which was not found in the earlier study, resulted from an ICD revision coding artifact. Several of these tumours were carcinomas and not sarcomas or tumours of bone tissue origin. Coding rules for the ICD-9 were modified to prevent metastatic bone tumours from being coded as primary bone tumours. As stated in the results section, under these rules there was no excess of bone cancer. A similar result was found by Satin et al. ${ }^{6}$

The overall results of this analysis support the conclusions of the meta-analysis of petroleum industry workers by Wong and Raabe. ${ }^{3}$ They found that the petroleum industry, in general, had a significantly low cancer mor- tality for all cancer sites combined and for cancers of the digestive system, stomach, and lung. These findings are confirmed by the current study. Wong and Raabe found mortality to be similar to that for the United States population for cancers of the skin, brain, pancreas, prostate, and kidney. These cancers show small increases in various subgroups in the current study, but the increases are not consistent, nor are they linked to increasing duration of employment in most of the job or unit specific subgroups.

The Wong and Raabe report did suggest that some of the refinery workers, especially those first employed before 1940, might have an increased risk of leukaemia. However, a follow up meta-analysis that looked specifically at leukaemia cell types ${ }^{10}$ showed no increased SMRs for acute myelogenous leukaemia or any of the other leukaemia cell types. The SMR for leukaemia for this cohort is as expected (101) and is only slightly increased (113) for those first employed before 1950. None of the increases for total leukaemia in the current study is consistent among the subgroups studied, nor is any linked to increasing duration of employment in most of the job or unit specific subgroups.

The SMRs for brain cancer in laboratory workers have decreased compared with those found in the earlier mortality analysis for this cohort. ${ }^{2}$ The earlier study showed SMRs of 210 and 221 for those employed as laboratory workers for $\geqslant 1$ year or $\geqslant 5$ years, respectively. For the most recent update, the SMRs for the same groups have declined to 164 and 169 . The original finding may reflect a chance cluster which has not continued. Even if the finding is not due to chance, there is no known exposure to chemical or physical agents for laboratory workers in the Texaco mortality study that has been causally associated with brain cancer. Also, laboratory practices have changed dramatically over the past 30 years, and exposure potentials have declined steadily through the automation of test procedures and advances in the design of laboratory ventilation.

Table 6 Continued

\begin{tabular}{|c|c|c|c|c|c|c|c|c|c|c|c|c|c|c|c|}
\hline \multicolumn{3}{|c|}{$\begin{array}{l}\text { Laboratory staff employed } \\
>5 \text { y white men } n=2478, \\
p-y=68286\end{array}$} & \multicolumn{3}{|c|}{$\begin{array}{l}\text { FCCU process unit employed } \\
>5 \text { y white men } n=1432 \text {, } \\
p-y=34975\end{array}$} & \multicolumn{3}{|c|}{$\begin{array}{l}\text { Pipefitter, boilermaker employed } \\
>5 \text { y white men } n=1974 \text {, } \\
p-y=53028\end{array}$} & \multicolumn{3}{|c|}{$\begin{array}{l}\text { Crude stills employed } \\
>5 \text { yhite men } n=1418 \text {, } \\
p-y=35270\end{array}$} & \multicolumn{4}{|c|}{$\begin{array}{l}\text { Motor oil units employed } \\
>5 \text { y white men } n=619 \text {, } \\
p-y=17782\end{array}$} \\
\hline $\begin{array}{l}\text { Observed } \\
\text { deaths }\end{array}$ & $S M R$ & $95 \% C I$ & $\begin{array}{l}\text { Observed } \\
\text { deaths }\end{array}$ & $S M R$ & $95 \% C I$ & $\begin{array}{l}\text { Observed } \\
\text { deaths }\end{array}$ & $S M R$ & $95 \% C I$ & $\begin{array}{l}\text { Observed } \\
\text { deaths }\end{array}$ & $S M R$ & $95 \% C I$ & $\begin{array}{l}\text { Observed } \\
\text { deaths }\end{array}$ & ${ }^{d} S M R$ & $95 \% C I$ & \\
\hline 171 & 67 & 57 to 78 & 141 & 93 & 78 to 110 & 204 & 88 & 76 to 101 & 136 & 69 & 57 to 81 & 86 & 98 & 79 to & 121 \\
\hline 39 & 60 & 42 to 81 & 38 & 95 & 67 to 130 & 48 & 75 & 56 to 100 & 37 & 65 & 46 to 90 & 24 & 99 & 63 to & 147 \\
\hline 5 & 50 & 16 to 117 & 4 & 62 & 17 to 159 & 11 & 100 & 50 to 180 & 5 & 49 & 16 to 114 & 6 & 142 & 52 to & 309 \\
\hline 25 & 104 & 67 to 153 & 14 & 96 & 53 to 161 & 15 & 67 & 37 to 110 & 7 & 35 & 14 to 72 & 6 & 70 & 25 to & 152 \\
\hline 6 & 47 & 17 to 102 & 10 & 129 & 62 to 237 & 10 & 83 & 40 to 153 & 13 & 124 & 66 to 212 & 6 & 131 & 48 to & 285 \\
\hline 45 & 51 & 37 to 68 & 32 & 63 & 43 to 90 & 64 & 85 & 66 to 109 & 35 & 58 & 41 to 81 & 19 & 68 & 41 to & 107 \\
\hline 0 & 0 & 0 to 504 & 0 & 0 & 0 to 801 & 2 & 259 & 29 to 935 & 0 & 0 & 0 to 525 & 1 & 336 & 4 to 1 & 1869 \\
\hline 7 & 149 & 60 to 307 & 5 & 191 & 62 to 446 & 4 & 102 & 27 to 260 & 1 & 33 & 0 to 184 & 1 & 72 & 1 to & 400 \\
\hline 21 & 97 & 60 to 148 & 13 & 94 & 50 to 161 & 21 & 97 & 60 to 149 & 19 & 89 & 53 to 138 & 10 & 117 & 56 to & 215 \\
\hline 5 & 69 & 22 to 161 & 1 & 21 & 0 to 119 & 6 & 80 & 29 to 175 & 6 & 83 & 30 to 180 & 5 & 170 & 55 to & 396 \\
\hline 1 & 16 & 0 to 89 & 7 & 193 & 77 to 398 & 7 & 127 & 51 to 261 & 7 & 154 & 62 to 317 & 2 & 98 & 11 to & 352 \\
\hline 11 & 169 & 84 to 302 & 5 & 140 & 45 to 327 & 3 & 56 & 11 to 165 & 2 & 51 & 6 to 183 & 6 & 314 & 115 to & 684 \\
\hline 20 & 84 & 51 to 129 & 25 & 179 & 116 to 264 & 22 & 104 & 65 to 157 & 16 & 89 & 51 to 144 & 7 & 88 & 35 to & 181 \\
\hline 2 & 60 & 7 to 215 & 3 & 143 & 29 to 417 & 2 & 61 & 7 to 219 & 2 & 69 & 8 to 250 & 1 & 79 & 1 to & 437 \\
\hline 8 & 85 & 37 to 167 & 8 & 142 & 61 to 280 & 14 & 160 & 88 to 269 & 3 & 39 & 8 to 114 & 4 & 121 & 33 to & 310 \\
\hline 7 & 80 & 32 to 165 & 13 & 264 & 140 to 452 & 3 & 42 & 8 to 122 & 10 & 172 & 82 to 317 & 2 & 76 & 9 to & 274 \\
\hline 5 & 182 & 59 to 425 & 3 & 186 & 37 to 543 & 6 & 237 & 87 to 516 & 2 & 91 & 10 to 328 & 2 & 208 & 23 to & 750 \\
\hline
\end{tabular}


Cancer of other lymphatic tissue is increased in several job unit specific analyses including workers employed on the fluid catalytic cracking units, the crude units, and as pipefitters. This cause of death category is composed of three different types of lymphohaematopoietic cancers including lymphoma, multiple myeloma, and polycythemia vera. The contribution of each of these causes of death to this result will be examined in the accompanying paper.

We have no explanation for the significant deficit for mortality from leukaemia for those first employed after $1950 \quad(S M R=50)$. It is unlikely that insufficient latency is responsible. The SMR for leukaemia is much lower than those for many of the solid tumours that are often assumed to have a longer induction period than leukaemia.

The Texaco mortality study update has several strengths, especially compared with other company studies of petroleum workers. The cohort is the largest in the petroleum industry including over 28000 people from many places. More than half of the cohort was employed in the industry for $>25$ years, and its mortality experience has been studied for 47 years (1947-93). Vital status is unknown for $<3 \%$ for the entire cohort, and the number of missing death certificates is $<2 \%$. Also, it is the only reported large study of refinery workers which includes information about the cohort members' complete work histories and the only one in which many analyses by both individual jobs and units as well as grouped jobs and units have been performed. In recent years, it has become common in the petroleum industry to use contract workers for maintenance activities and for the remaining workers to work on multiple crafts or units. However, this practice did not begin until the 1980s, and it is thus unlikely that it would have had an influence on the causes of death of interest which have $\geqslant 20$ years of latency.

The study does have several limitations. As with other mortality studies, it has the problems associated with diagnoses from the death certificates for the cause of death-for example, diagnostic accuracy and specificity, and comparability of ICD codes over time. Although the cohort is one of the largest studied in the petroleum industry, many of the subgroups analysed are small in size, and for many of the causes of death, the number of deaths is small making the results inconclusive and difficult to interpret. Because of the numerous analyses done, some isolated increases in SMRs would be expected by chance alone.

Although the employee's complete work history was used, information about the specific chemicals associated with each of the job and unit combinations is not available nor is there any sampling data on industrial hygiene covering the first 30 years of the study. Jobs and units with similar responsibilities were grouped together for the analyses as a surrogate for exposures, but provide little information to link exposure to outcome.

\section{Conclusion}

This paper reports the overall results of the Texaco mortality study update. The results showed a favourable mortality experience for refinery, petrochemical, and research employees compared with the general United States population. Most causes of death showed either similar mortality or a significant deficit among the Texaco employees. There was a $21 \%$ deficit for all deaths for the total cohort which translates into an increased life expectancy of 2.9 years for Texaco refinery, petrochemical, and research workers compared with United States white men. ${ }^{11}$

Only a few increases were seen consistently in several of the analysis subgroups, which were significantly increased, or which have been found in other studies of petroleum industry workers. These include increases for cancer of other lymphatic tissue in workers employed on the fluid catalytic cracking unit and crude stills, and for benign and unspecified neoplasms and brain cancer in workers employed in the laboratories and on the units related to motor oil. Additional analyses of these results as well as results specific to leukaemia cell types and mortality from mesothelioma will be discussed in a later report.

1 Divine BJ, Barron V, Kaplan SD. Texaco mortality study I. Mortality among white male refinery, petrochemical, and Mortality among white male refinery, petroch
research workers. F Occup Med 1985;27:445-7.

2 Divine BJ, Barron V. Texaco mortality study II. Patterns of mortality among white males by specific job groups. Am $\mathcal{F}$ Ind Med 1986;10:371-81.

3 Wong O, Raabe GK. Critical review of cancer epidemiology in petroleum industry employees, with a quantitative metaanalysis by cancer site. Am f Ind Med 1989;15:283-310.

4 McCraw DS, Joyner RE, Cole P. Excess leukemia in a refinery population. F Occup Environ Med 1985;27:220-2.

5 Nelson NA, Van Peneen PFD, Blanchard AG. Mortality in a recent oil refinery cohort. F Occup Environ Med 1987;29: $610-2$.

6 Satin KP, Wong O, Yuan LA, et al. A 50-year mortality follow-up of a large cohort of oil refinery workers in Texas. f Occup Environ Med 1996;38:492-506.

7 Shallenberger LG, Acquavella JF, Donaleski D. An updated Shallenberger LG, Acquavella JF, Donaleski D. An updated
mortality study of workers in three major United States refineries and chemical plants. Br F Ind Med 1992;49:3454.

8 Tsai SP, Waddell LC, Gilstrap EL, et al. Mortality among maintenance employees potentially exposed to asbestos in a refinery and petrochemical plant. Am f Ind Med 1996;29: 89-98.

9 Monson RR. Analysis of relative survival and proportionate mortality. Computer Biomed Res 1974;7:325-32.

10 Wong O, Raabe GK. Cell-type specific leukemia analyses in a combined cohort of more than 208000 petroleum workers in the United States and the United Kingdom. Reg Toxicol Pharmacol 1995;21:307-21.

11 Tsai SP, Hardy RJ, Wen CP. The standardized mortality ratio and life expectancy. Am f Epidemiol 1992;135:824-31. 